\title{
KINERJA SUBSIDI PUPUK DI INDONESIA
}

\section{PERFORMANCE OF FERTILIZER SUBSIDY IN INDONESIA}

\author{
Aida Ratna Zulaiha*), Rita Nurmalina**), dan Bunasor Sanim***) \\ *) Direktorat Penelitian dan Pengembangan, Komisi Pemberantasan Korupsi \\ J1 Kuningan Persada K4 Jakarta Selatan 12950 \\ ${ }^{* *}$ Departemen Agribisnis, Fakultas Ekonomi dan Manajemen, Institut Pertanian Bogor \\ Jl. Kamper, Wing 4 Level 5, Kampus IPB Dramaga, Bogor 16680 \\ ${ }^{* * *}$ Sekolah Bisnis, Institut Pertanian Bogor \\ Jl. Raya Pajajaran, Bogor 16151
}

\begin{abstract}
The implementation of fertilizer subsidies in Indonesia involves large government budgets, varied stakeholders, and complex business processes. Therefore, the performance of the government on the investment in fertilizer subsidies, worth almost Rp40 trillion or more than $30 \%$ of the total non-energy subsidies, needs to be analyzed. The objective of this research was to analyze the performance of fertilizer subsidies through factors affecting fertilizer subsidy budget and 'six appropriate achievements' of the fertilizer subsidies in Indonesia. Panel data regression and descriptive analysis were conducted on the secondary data of 2011-2015 in 32 provinces. The results showed that fertilizer subsidy performance, as reflected by the availability of fertilizer subsidy budget, was significantly affected by the absorption of subsidized fertilizer in the previous year, government debt to fertilizer producers, assistance fund to provincial government, and GDRP. With a value over 90 percent, the performances of fertilizer subsidies in 'six appropriate types', were achieved on 'appropriate type' and 'appropriate quantity'. The 'appropriate location' of each province was in the range of 30-96\%.
\end{abstract}

Keywords: fertilizer subsidy, panel data regression, descriptive analysis, subsidy budget, six appropriate

\begin{abstract}
Abstrak: Pelaksanaan subsidi pupuk di Indonesia melibatkan anggaran pemerintah yang besar, pemangku kepentingan yang beragam dan bisnis proses yang kompleks. Oleh karena itu, investasi pemerintah dalam subsidi pupuk yang nilainya hampir Rp40 triliun atau lebih $30 \%$ dari total subsidi non energi tersebut perlu dianalisis kinerjanya. Tujuan dari penelitian ini adalah menganalisis kinerja subsidi pupuk melalui faktor-faktor yang memengaruhi anggaran subsidi pupuk dan pencapaian 'enam tepat' subsidi pupuk di Indonesia. Regresi data panel dan analisis diskriptif dilakukan dengan menggunakan data sekunder tahun 2011-2015 dan 32 provinsi. Hasil analisis menunjukkan bahwa kinerja subsidi pupuk yang dicerminkan oleh ketersediaan anggaran subsidi pupuk signifikan dipengaruhi oleh penyerapan pupuk bersubsidi pada tahun sebelumnya, hutang subsidi pemerintah kepada produsen, dana pendampingan pemerintah pusat kepada pemerintah provinsi dan PDRB. Dengan nilai di atas $90 \%$, kinerja subsidi pupuk dalam 'enam tepat' tercapai pada 'tepat jenis', dan 'tepat jumlah'. Kinerja subsidi pupuk dalam 'tepat tempat' pada tiap provinsi tercapai pada kisaran $30-96 \%$.
\end{abstract}

Kata kunci: subsidi pupuk, regresi data panel, analisis diskriptif, anggaran subsidi, enam tepat

\footnotetext{
${ }^{1}$ Alamat Korespondensi:

Email: aida.zulaiha@gmail.com
} 


\section{PENDAHULUAN}

Subsidi pupuk merupakan salah satu jenis subsidi pemerintah yang masih dipertahankan dalam rangka peningkatan kedaulatan pangan nasional yang nilainya terus mengalami peningkatan setiap tahunnya. Jika pada tahun 1992 anggaran negara untuk membiayai subsidi pupuk hanya sekitar Rp175 miliar maka pada APBNP tahun 2015 terjadi peningkatan menjadi Rp39,48 triliun. Nota Keuangan dan RAPBN 2016 melaporkan subsidi pupuk yang disalurkan melalui BUMN produsen pupuk pada periode 2010-2014 mengalami kenaikan rata-rata 3,4\% Peningkatan yang signifikan pada subsidi pupuk tahun 2015 dikarenakan terdapatnya alokasi pembayaran kurang bayar pada tahun-tahun sebelumnya. Anggaran subsidi pupuk tahun 2016 sebesar Rp30,06 triliun yang hanya dialokasikan untuk pembayaran subsidi tahun berjalan, merupakan anggaran yang cukup besar karena berkontribusi 37,4\% dari nilai total subsidi non energi yang sebesar Rp80,41 triliun.

Kebijakan subsidi pupuk sejak pertama kali ditetapkan di sekitar tahun 1970-an terus mengalami penyempurnaan hingga ditetapkannya subsidi pupuk dengan sistem distribusi tertutup saat ini. Subsidi pupuk dengan pola tertutup dimulai tahun 2009, ditandai dengan diberlakukannya rencana definitif kebutuhan kelompok (RDKK), dimana rencana kebutuhan pupuk dari tiap wilayah dibuat dahulu untuk memudahkan pembuatan perkiraan kebutuhan volume pupuk dan kebutuhan biaya (KPPN/Bappenas, 2011). Keterlibatan stakeholders yang beragam dengan tugas dan fungsi sesuai dengan peraturan yang ditetapkan serta bisnis proses yang kompleks juga menjadi bagian dari kebijakan pupuk bersubsidi ini.

Bisnis proses subsidi pupuk, meliputi perencanaan, produksi, distribusi, konsumsi dan pengawasan pupuk bersubsidi. Tiap tahapan bisnis proses tersebut melibatkan stakeholders beragam, terdiri dari DPR, Kementerian Pertanian, Kementerian BUMN, Kementerian Perdagangan, PT Pupuk Indonesia, Pemerintah Daerah, Pabrik Pupuk, Distributor, Pengecer, Kelompok Tani dan Petani. Kinerja masingmasing stakeholders dan tahapan bisnis proses tersebut menjadi faktor-faktor yang memengaruhi kinerja subsidi pupuk secara keseluruhan di Indonesia.
Beberapa hasil penelitian menunjukkan bahwa kebijakan subsidi pupuk yang sudah berjalan lebih dari 50 tahun terakhir masih banyak masalah. Rachman (2009) menyoroti permasalahan utama kinerja subsidi pupuk pada sisi perencanaan, distribusi dan pengawasan, termasuk keterbatasan anggaran belanja pemerintah. Oleh karena itu, diperlukan perbaikan meliputi aspek teknis, manajemen dan regulasi supaya efektivitas pelaksanaan subsidi pupuk dapat tercapai. Hendrawan et al. (2012) dengan menggunakan metoda ANP (Analysis Network Proses) menemukan bahwa faktorfaktor yang menentukan kebijakan subsidi meliputi: 1) faktor lingkungan, dominan pada ketersediaan dana subsidi pupuk, pertumbuhan ekonomi, dan inflasi (ekonomi), serta komitmen DPR (politik); 2) tujuan subsidi, dominan pada ketersediaan pupuk; 3) jenis subsidi, dominan pada pupuk anorganik; 4) peran aktor, dominan kementerian pertanian, BUMN produsen dan distributor pupuk; 5) distribusi, dominan pada pengawasan; serta 6) pola subsidi dan sistem ditribusi terutama adalah subsidi tidak langsung.

Hasil penelitian-penelitian tersebut menguatkan dugaan bahwa keputusan pemerintah untuk membiayai subsidi pupuk akan ditentukan oleh faktor-faktor yang berada dalam bisnis proses subsidi pupuk mulai dari perencanaan, produksi, distribusi, konsumsi hingga pengawasan. Faktor eksternal lain yang relatif sulit dikendalikan yaitu kondisi makroekonomi dan politik juga diperkirakan akan memengaruhi keputusan pemerintah dalam menetapkan anggaran subsidi pupuk.

Mengingat pentingnya pupuk subsidi dalam meningkatkan ketahanan pangan nasional, pemerintah menyatakan pupuk bersubsidi sebagai barang dalam pengawasan. Terdapat lima jenis pupuk yang disubsidi, yaitu urea, SP36, ZA, NPK dan organik dengan ruang lingkup pengawasan mencakup pengadaan dan penyaluran, termasuk jenis, jumlah, mutu, wilayah pemasaran, harga eceran tertinggi dan waktu pengadaan dan penyaluran. Ruang lingkup pengawasan tersebut kemudian dikenal dengan istilah 'enam tepat' pada subsidi pupuk yang merujuk pada tepat jenis, tepat jumlah, tepat mutu, tepat tempat, tepat harga dan tepat waktu. Oleh karena itu, kinerja subsidi pupuk juga dicerminkan oleh tercapainya prinsip "enam tepat" dalam subsidi pupuk yaitu tepat jumlah, tepat tepat tempat, tepat waktu, tepat mutu, tepat jenis, dan tepat harga. 
Darwis dan Supriyati (2013) menyebut bahwa kebijakan subsidi pupuk diarahkan untuk mencapai tujuan antara yaitu meningkatkan kemampuan petani untuk membeli pupuk dalam jumlah yang sesuai dengan dosis anjuran pemupukan berimbang sesuai lokasi. Namun, sebagai suatu program subsidi dengan target yang sangat luas, subsidi pupuk menghadapi berbagai masalah. Setidaknya terdapat tiga masalah penting dalam program subsidi pupuk, yaitu penyelewengan distribusi pupuk bersubsidi, kesenjangan antara ketersediaan dan kebutuhan, dan bias sasaran/target (Susila, 2010). Hasil penelitian lain menginformasikan bahwa petani yang mengelola lahan kurang dari 0,5 ha hanya menerima $40 \%$ dari total subsidi pupuk (Rachman dan Sudaryanto, 2010). Ketidakefektifan kebijakan subsidi pupuk di Indonesia ditunjukkan oleh tidak tercapainya azas 6 tepat, yaitu tepat jumlah, tepat jenis, tepat mutu, tepat harga, tepat tempat dan tepat waktu (Syafa'at et al. 2006).

Permasalahan yang akan dijawab dalam penelitian ini adalah faktor-faktor apa saja yang memengaruhi anggaran subsidi pupuk dan bagaimana kinerja subsidi pupuk dalam mencapai 'enam tepat' di Indonesia? Dengan demikian tujuan dari penelitian ini adalah mengukur kinerja pupuk bersubsidi melalui analisis faktor-faktor yang memengaruhi anggaran subsidi pupuk; dan menganalisis pencapaian output 'enam tepat' pada pupuk bersubsidi.

Ruang lingkup penelitian adalah pelaksanaan kebijakan subsidi pupuk Indonesia Tahun 2011-2015 di 32 provinsi di Indonesia. Jenis pupuk yang disubsidi adalah urea, SP36, ZA, NPK dan Organik. Hanya tiga dari enam tepat yang akan dianalisis pada penelitian ini, yaitu tepat jenis, tepat tempat dan tepat jumlah. Informasi yang dikumpulkan terkait dengan data kinerja subsidi pupuk pada perencanaan, produksi, distribusi dan konsumsi, yang melibatkan stakeholders utama kelompok tani, PT Pupuk Indonesia, Kementerian Pertanian, Kementerian Keuangan, dan Kementerian Perdagangan.

\section{METODE PENELITIAN}

Hingga saat ini, pertanian masih merupakan sektor strategis dalam pembangunan nasional terutama dalam rangka mencapai kedaulatan pangan. Walaupun sektor pertanian merupakan sektor prioritas, namun keterbatasan anggaran pendapatan dan belanja negara (APBN) memaksa pemerintah harus memilih dengan cermat program apa yang tepat dijalankan dan memberikan dampak yang signifikan. Subsidi pupuk merupakan salah satu program pertanian di sektor hulu yang diputuskan pemerintah untuk tetap dipertahankan.

Bisnis proses dalam subsidi pupuk melibatkan petani, kelompok tani, pemerintah daerah, Kementerian Pertanian, Kementerian Keuangan, Kementerian Perdagangan, Kementerian BUMN, DPR, BUMN produsen pupuk beserta pabrik pupuk, distributor, pengecer, yang terlibat secara parsial maupun bersama mulai dari perencanaan, produksi, distribusi, konsumsi hingga pengawasan pupuk bersubsisi. Keterlibatan banyak stakeholders ini menunjukkan bahwa bisnis proses subsidi pupuk cukup komplek. Di sisi lain, kebijakan subsidi pupuk di Indonesia dengan sistem distribusi tertutup yang diterapkan pada tujuh tahun terakhir relatif berjalan stabil setelah beberapa kali mengalami perubahan pola subsidi. Oleh karena itu analisis kinerja terhadap subsidi pupuk layak dilakukan.

Analisis kinerja subsidi pupuk dilakukan melalui identifikasi faktor-faktor apa yang menentukan besaran anggaran subsidi pupuk, bersumber dari faktor internal dalam bisnis proses subsidi pupuk, makroekonomi maupun politik. Analisis berikutnya adalah mengukur ketercapaian 'enam tepat' dengan membandingkan antara angka realisasi dengan angka perencanaan. Kerangka pemikikiran ditunjukkan pada Gambar 1.

Penelitian ini menggunakan data panel (longitudinal data) yang memiliki dimensi ruang (individu) dan waktu. Jenis data sekunder dengan time series 20112015, beserta cross section 32 provinsi. Periode waktu lima tahun terakhir merujuk pada periode penerapan subsidi pupuk dengan sistem distribusi tertutup yang telah stabil. Sedangkan hanya 32 provinsi yang dipilih, karena dua provinsi, yaitu DKI Jakarta dan Kalimantan Utara tidak memiliki kecukupan data.

Jenis data sekunder yang dikumpulkan terkait dengan kinerja dan output pupuk bersubsidi serta data kondisi makroekonomi yang relevan pada tingkat nasional, provinsi serta wilayah produksi dan distribusi. Sumber data fisik dan online diperoleh dari PSE-KP, BPS, PT Pupuk Indonesia beserta anak perusahaannya, Kementerian Keuangan, Ditjen Sarana dan Prasarana Pertanian, Bank Indonesia, Kementerian Perdagangan 
dan Instansi lain terkait. Data-data sekunder lain seperti dokumen perusahaan, laporan tahunan kementerian, juga dikumpulkan dan dianalisis sesuai dengan kebutuhan penelitian.

Analisis ekonometrika melalui pendugaan model panel data statis dilakukan untuk mengidentifikasi faktorfaktor yang memengaruhi subsidi pupuk. Sedangkan analisis deskriptif dilakukan dalam rangka mengukur output pelaksanaan pupuk bersubsidi dalam tercapainya enam tepat subsidi pupuk, yaitu tepat jumlah, tepat jenis, tepat tempat, tepat mutu, tepat harga dan tepat waktu. Hanya tepat jumlah, tepat jenis dan tepat tempat yang dianalisis dalam penelitian ini dikarenakan ketidaksediaan data sekunder untuk mengukur tepat mutu, tepat harga dan tepat waktu.
1. Analisis faktor-faktor yang memengaruhi anggaran subsidi pupuk

Tahap-tahap dalam melakukan pendugaan metode estimasi model regresi dengan menggunakan data panel meliputi: 1) memilih model estimasi yang dianggap paling tepat dari tiga jenis model data panel apakah common effect model, fixed effect model atau random effect model; 2) melakukan pengujian asumsi klasik untuk data panel, yaitu uji multikolinieritas dan heteroskedastisitas dan; 3) interpretasi regresi data panel dengan melakukan pengujian kelayakan model estimasi (goodness of fit). Dalam penelitian ini alat bantu analisis yang digunakan adalah software statistik STATA-14.

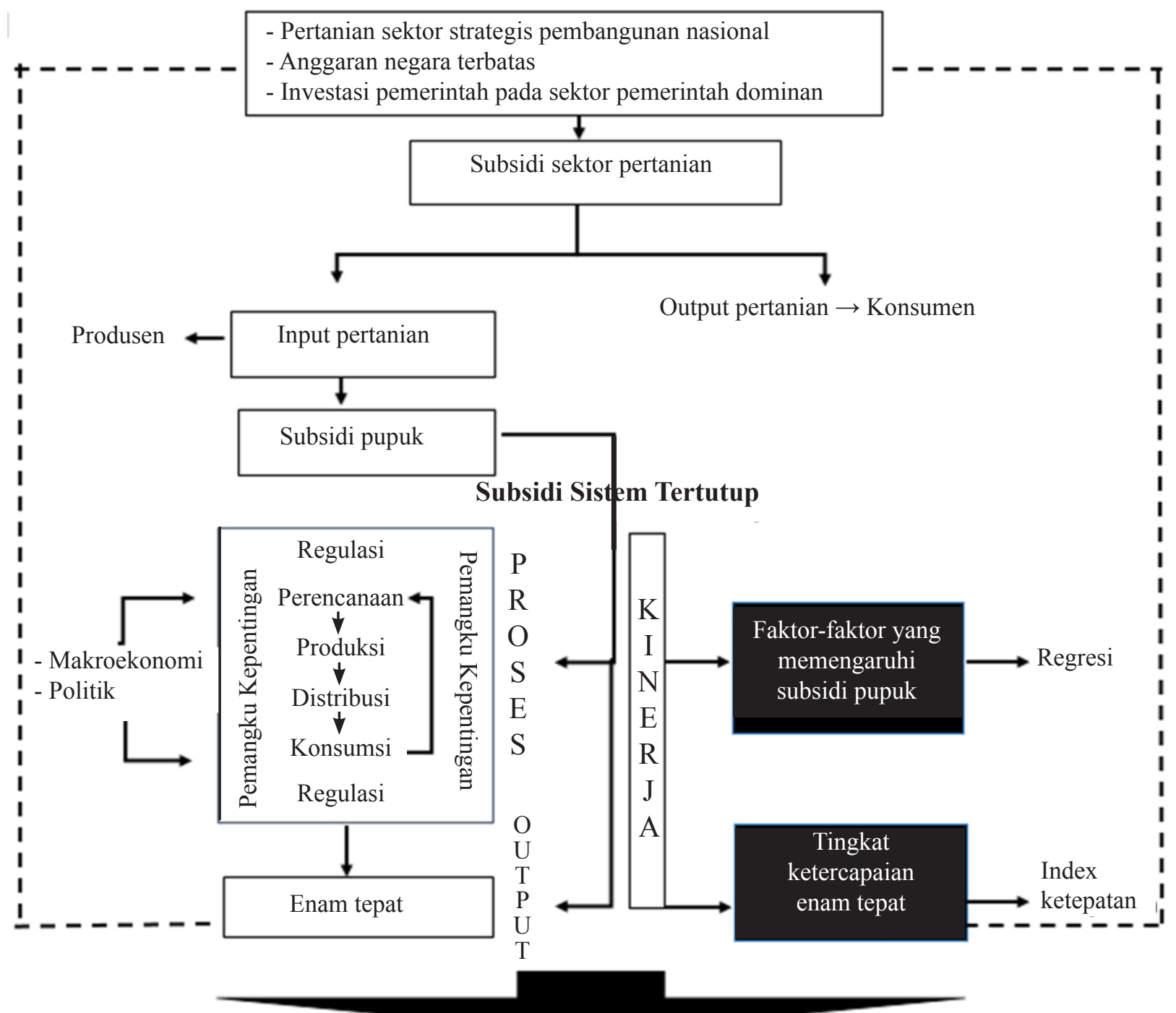

Implikasi Manajerial

Gambar 1. Kerangka pemikiran penelitian 
Model analisis regresi untuk faktor-faktor yang memengaruhi subsidi pupuk dapat dituliskan dalam persamaan berikut:

$$
\begin{aligned}
\mathrm{S}_{\mathrm{it}}= & \mathrm{b} 1 \mathrm{i}+\mathrm{b} 2 \mathrm{X} 1_{\mathrm{it}}+\mathrm{b} 3 \mathrm{X} 2_{\mathrm{it}}+\mathrm{b} 4 \mathrm{X} 3_{\mathrm{it}}+\mathrm{b} 5 \mathrm{X} 4_{\mathrm{it}}+\mathrm{b} 6 \mathrm{X} 5_{\mathrm{it}} \\
& +\mathrm{b} 7 \mathrm{X} 6_{\mathrm{it}}+\mathrm{e}_{\mathrm{it}}
\end{aligned}
$$

Angg_subsidi ${ }_{\mathrm{it}}=\quad \mathrm{b} 1_{\mathrm{i}}+\mathrm{b} 2 \mathrm{Serap} \mathrm{t}-1_{\mathrm{it}}+\mathrm{b} 3 \mathrm{RDKK}_{\mathrm{it}}+$ b4Inflasi ${ }_{\text {it }}+$ b5Hutang_subsidi ${ }_{\text {it }}+$ b6Dana_pemerintah ${ }_{\mathrm{it}}+\mathrm{b}_{\mathrm{PDRB}}$ $+e_{i t}$

Variabel dependen pada model ini adalah nilai anggaran subsidi pupuk yang disediakan pemerintah setiap tahunnya pada tiap provinsi (Angg_Subsidi), dengan variabel independen: 1) jumlah penyerapan pupuk subsidi pada tahun sebelumnya (Serap t-1); 2) jumlah perencanaan kebutuhan pupuk bersubsidi berdasar usulan dalam rencana definitif kebutuhan kelompok (RDKK); 3) inflasi ibukota provinsi (Inflasi); 4) hutang subsidi pemerintah kepada produsen/BUMN pupuk (Hutang_subsidi); 5) dana pendampingan pemerintah dalam bentuk dana dekonsentrasi dan tugas perbantuan yang disalurkan ke provinsi melalui Ditjen PSP Kementerian Pertanian (Dana_pemerintah); 6) produk domestik regional bruto provinsi (PDRB). Analisis faktor-faktor yang memengaruhi subsidi pupuk dilakukan dengan menguji signifikansi dan pengaruh variabel-variabel independen terhadap variabel dependen.

\section{Pencapaian enam tepat dalam subsidi pupuk}

Analisis deskriptif dilakukan dalam rangka mengukur output dari pelaksanaan pupuk bersubsidi, melalui tercapainya 'enam tepat' dalam subsidi pupuk. Analisis Hpencapaian 'enam tepat' dilakukan dengan mengacu pada apa yang pernah dilakukan oleh Hutagaol dan Asmara (2007) yang mengukur keefektifan pelaksanaan program 'beras miskin'berdasarkan indikator kinerja pelaksanaan 'beras miskin', yaitu tepat sasaran, tepat jumlah, tepat harga, tepat waktu, tepat administrasi. Program dinyatakan efektif dalam hal tepat sasaran jika 'beras miskin' hanya diberikan pada keluarga miskin yang terdaftar secara resmi. Tepat jumlah jika jumlah 'beras miskin' yang dibeli oleh keluarga sasaran sama dengan jumlah yang ditetapkan dalam musyawarah tim 'beras miskin' daerah. Tepat harga jika harga beras yang dibayar sasaran sesuai dengan harga 'beras miskin' yang ditetapkan pemerintah. Namun, keterbatasan data sekunder yang tersedia, pengukuran efektivitas dalam pencapaian 'enam tepat' dalam penelitian ini hanya dilakukan terhadap 'tiga tepat' yaitu 'tepat jumlah', 'tepat jenis', dan 'tepat tempat'.

\section{a) Tepat Jumlah}

Ketepatan jumlah pupuk subsidi mengacu pada pemenuhan alokasi pupuk oleh PT. Pupuk Indonesia beserta produsennya (PIHC) sesuai ketetapan dalam Peraturan Menteri Pertanian. Perbandingan dilakukan antara realisasi jumlah per jenis pupuk subsidi yang terjual dari PT. Pupuk Indonesia dengan jumlah per jenis pupuk sesuai perjanjian Public Service Obligation (PSO).

$\mathrm{J}=(\mathrm{Ja} / \mathrm{Js}) \times 100 \%=($ Realisasi penjualan pupuk subsidi $\mathrm{PIHC} /$ Jumlah dalam PSO ) x100\%

b) Tepat jenis

Efektivitas tepat jenis pupuk bersubsidi diukur dengan membandingkan realisasi penjualan pupuk bersubsidi berdasar jenis (urea, ZA,SP36, NPK, Organik) oleh produsen dengan penugasan/target (PSO) pemerintah kepada produsen.

$\mathrm{N}=(\mathrm{Na} / \mathrm{Ns}) \times 100 \%=$ (Realisasi penjualan jenis pupuk oleh produsen/Penugasan penjualan jenis pupuk kepada produsen) $\times 100 \%$

\section{c) Tepat tempat}

Dalam penyaluran pupuk subsidi, ketepatan tempat menunjukkan bagaimana produsen bisa mendistribusikan produksinya ke wilayah yang ditetapkan dalam PSO. Dalam penelitian ini, wilayah yang dimaksud adalah provinsi yang menjadi lokasi distribusi pupuk bersubsidi.

$\mathrm{T}=(\mathrm{Ta} / \mathrm{Ts}) \times 100 \%=($ Realisasi berdasarkan provinsi $/$ Alokasi provinsi dalam PSO) $\mathrm{x} 100 \%$

Kriteria ketercapaian efektivitas ditunjukkan oleh skala efektivitas (Champion, 1981) dalam Basic Statistic for Statistical Research sebagai berikut: 0-25\% (tidak efektif); 25-50\% (sedikit efektif); 50-75\% (cukup efektif);75-100\% (sangat efektif). 


\section{HASIL}

\section{Kinerja Subsidi Pupuk melalui Analisis Faktor- faktor yang Memengaruhi Anggaran Subsidi Pupuk}

Hasil Chow Test dan Uji Hausman yang dilakukan menunjukkan bahwa fixed effect adalah model estimasi yang paling tepat. Hasil itu ditunjukkan oleh P Value $\left(\right.$ Prob $\left.>\mathrm{Chi}^{2}\right)<\alpha(0,05)$ maka H1 diterima atau pilihan terbaik adalah fixed effect daripada random effect. Asumsi uji klasik yang dilakukan hanyalah uji multikolinieritas dan heteroskedastisitas. Uji normalitas dan autokorelasi tidak dilakukan mengingat data yang dipakai dalam penelitian ini adalah data sekunder dan data panel yang tidak memerlukan dua uji asumsi klasik tersebut.

Interpretasi dari hasil pengujian regresi data panel meliputi uji signifikansi serentak, uji signifikansi parsial, uji goodness of fit test, dan persamaan regresi didasarkan pada model terbaik yang telah dipilih pada bagian sebelumnya, yaitu fixed effect. Tabel 1 menjelaskan faktor-faktor yang memengaruhi anggaran subsidi pupuk berdasarkan model fixed effect yang didapatkan dari hasil analisis STATA 14.

Pada uji signifikansi serentak, H0 akan ditolak jika nilai F-statistik $>$ nilai $\mathrm{F}$ tabel atau bila $($ Prob $>\mathrm{F})<$ $\alpha$. Jika nilai dari $($ Prob $>$ F $)=0$ berarti $($ Prob $>$ F $)<\alpha$ $(0,05)$. Pada hasil pengolahan data dengan STATA 14 ditunjukkan bahwa Nilai Prob $>\mathrm{F}=0,0000<\alpha$ $(0,05)$ yang menunjukkan bahwa model yang dipilih layak untuk mengintepretasikan pengaruh variabel independen terhadap variabel dependen.

Uji signifikansi parsial akan melihat per variabel apakah masing-masing independen variabel secara signifikan berpengaruh terhadap dependen variabel. Pengujian dengan t-test di mana $\mathrm{H} 0$ akan ditolak bila nilai $\mathrm{t}$-statistik $>$ nilai kritis t-tabel atau bila $(\mathrm{P}>|\mathrm{t}|)<\alpha(0,05)$. Hasil analisis menunjukkan bahwa pada taraf nyata $1 \%$, variabel-variabel yang berpengaruh signifikan positif terhadap anggaran subsidi pupuk adalah jumlah penyerapan pupuk pada tahun sebelumnya $(0,001)$, dana pendampingan pemerintah dalam bentuk dana dekonsentrasi dan tugas perbantuan pemerintah kepada provinsi $(0,000)$ serta PDRB harga berlaku $(0,000)$. Hutang subsidi pemerintah kepada BUMN Pupuk $(0,002)$ juga berpengaruh signifikan dengan tanda sebaliknya.Variabel yang tidak berpengaruh signifikan secara statistik baik pada taraf nyata $1 \%, 5 \%, 10 \%$ atau bahkan $15 \%$ adalah variabel usulan kebutuhan pupuk dalam $\operatorname{RDKK}(0,584)$ dan inflasi $(0,922)$ (Tabel 1).

Dalam rangka mengukur seberapa besar variasi dari nilai variabel dependen dapat dijelaskan oleh variasi nilai dari variabel independen dilakukan Uji Goodness of Fit. Pada uji fixed effect, ditunjukkan oleh nilai R-sq overall. Hasil analisis STATA 14 pada model faktorfaktor yang memengaruhi subsidi pupuk tersebut menunjukkan nilai R-sq overall 0,8998. Artinya, variasi besarnya anggaran subsidi pupuk sebesar $89,98 \%$ dapat diterangkan oleh variabel-variabel independen dalam model dan sisanya sebesar $10,02 \%$ ditentukan oleh variabel-variabel lain di luar model.

Tabel 1. Faktor-faktor yang memengaruhi anggaran subsidi pupuk

\begin{tabular}{lcc}
\hline \multicolumn{1}{c}{ Angg_subsidi } & Coef. & $\mathrm{P}>|\mathrm{t}|$ \\
\hline Serap_t-1 & 1741503 & $0,001^{*}$ \\
RDKK & 253071 & 0,584 \\
Inflasi & -761000000 & 0,922 \\
Hutang_subsidi & $-0,3303122$ & $0,002^{*}$ \\
Dana_pemerintah & 0,8978651 & $0,000^{*}$ \\
PDRB & 3,046505 & $0,000^{*}$ \\
consta & -744000000000 & $0,000 *$ \\
\hline
\end{tabular}

Keterangan: *signifikan pada taraf nyata $1 \%$ 
Hasil model estimasi terbaik fixed effect maka persamaan regresi yang dihasilkan adalah sebagai berikut:

$$
\begin{aligned}
\text { Angg_subsidi }_{\text {it }}= & -744000000000+1741503 \text { Serap } \\
& \text { t-1it }+253071 \mathrm{RDKK}_{\mathrm{it}}- \\
& 761000000 \text { Inflasi }_{\text {it }}-0,330 \text { Hutang }_{-} \\
& \text {subsidi }_{\text {it }}+0,898 \text { Dana_pemerintah }_{\text {it }} \\
& +3,047 \text { PDRB }_{\text {it }}+\mathrm{e}_{\text {it }}
\end{aligned}
$$

Persamaan regresi subsidi pupuk tersebut menjelaskan pada taraf nyata $1 \%$, peningkatan 1 ton penyerapan pupuk pada tahun sebelumnya, cateris paribus, akan meningkatkan anggaran subsidi pupuk sebesar 1.741.503 rupiah. Selain jumlah penyerapan pupuk subsidi tahun sebelumnya, pada tingkat kepercayaan 99\%, variabel lain yang memiliki pengaruh signifikan terhadap anggaran subsidi pupuk adalah hutang subsidi pemerintah kepada produsen pupuk, dana dekonsentrasi dan perbantuan pemerintah pusat kepada pemerintah provinsi serta PDRB.

Pengaruh yang signifikan dari jumlah penyerapan pupuk sebelumnya terhadap nilai anggaran subsidi pupuk yang disediakan pemerintah pada tahun tersebut menunjukkan bahwa data realisasi penggunaan pupuk subsidi pada tahun sebelumnya merupakan data yang menurut pemerintah dan DPR relevan dijadikan dasar untuk menyepakati besaran anggaran subsidi pupuk yang harus disediakan APBN tahun ini. Peningkatan penyerapan pupuk subsidi pada tahun sebelumnya menjadi acuan akan terjadi peningkatan kebutuhan pupuk pada tahun ini sehingga anggaran subsidi pupuk dalam APBN juga harus ditingkatkan.

Hutang subsidi pupuk pemerintah kepada produsen (PT. Pupuk Indonesia) berpengaruh signifikan negatif terhadap nilai anggaran subsidi pupuk, karena dengan APBN yang terbatas, jika pada tahun yang sama pemerintah juga harus membayar hutang subsidi pupuk, maka pemerintah dengan kesepakatan dari DPR akan membayar hutang subsidi pupuk tersebut dari anggaran subsidi pupuk yang disediakan APBN. Semakin besar nilai hutang pada tahun tersebut, semakin besar pula yang harus dibayarkan kepada produsen sehingga mengurangi jatah anggaran yang sedianya khusus dibelanjakan untuk subsidi pupuk.

Hasil penelitianArmas et al. (2010) menunjukkan bahwa belanja publik pertanian di Indonesia selama periode 2000-2008 sebagian besar dialokasikan untuk subsidi pupuk, kredit dan benih, namun belanja publik untuk subsidi pupuk tidak memiliki dampak positif terhadap pertumbuhan pertanian. Biaya subsidi umumnya tidak setimpal dengan manfaat yang diperoleh, bahkan sering menjadi tekanan politik sehingga subsidi menjadi permanen.

Suryana et al. (2016) menjelaskan bahwa faktor alokasi anggaran dan besarnya subsidi untuk setiap kilogram pupuk akan menjadi penentu besarnya total pupuk bersubsidi yang dapat disediakan pemerintah. Namun penghitungan yang dilakukan oleh Alimoeso (2010) menyebutkan bahwa anggaran untuk subsidi pupuk semakin terbatas dari tahun ke tahun sebagai akibat dari harga eceran tertinggi (HET) yang tidak naik. Pada tahun 2010 anggaran subsidi pupuk Rp11,3 trilyun, turun dari Rp17,5 trilyun pada tahun 2009. Karena HET tidak naik maka volume pupuk yang disubsidi berkurang.

Informasi penting dari penelitian ini selain berhasil mengidentifikasi variabel-variabel yang berpengaruh signifikan terhadap kebijakan penganggaran subsidi pupuk adalah tidak adanya pengaruh signifikan dari usulan kebutuhan pupuk yang dituangkan setiap tahunnya melalui RDKK terhadap anggaran subsidi pupuk yang disiapkan pemerintah setiap tahunnya. Tidak adanya pengaruh RDKK ini menjadi relevan jika RDKK yang disusun ternyata tidak mencerminkan kebutuhan riil petani terhadap pupuk bersubsidi. Hasil penelitian PSE-KP (2006) menyatakan bahwa masih terjadi kesenjangan antara ketersediaan dan kebutuhan pupuk yang muncul dikarenakan kesulitan dalam membuat data yang akurat mengenai kebutuhan pupuk bersubsidi. Prakiraan kebutuhan pupuk sering dibuat secara agregat dengan memperhitungkan luas tanam dan takaran pupuk secara umum. Kenyataannya, takaran penggunaan pupuk bervariasi, baik karena perbedaan luas lahan maupun tingkat kesadaran petani terhadap manfaat pupuk. Penelitian Safitri et al. (2013) menjelaskan kurangnya sosialisasi sistem RDKK terhadap kelompok tani/petani mengakibatkan petani kurang mengoptimalkan haknya dalam memperoleh pupuk sehingga pemerintah dianggap belum berhasil dalam sosialisasi program pupuk subsidi.

\section{Kinerja Subsidi Pupuk dalam Pencapaian Enam Tepat}

Pengukuran deskriptif dengan membandingkan antara perencanaan dan realisasi dilakukan untuk mengukur 
kinerja subsidi pupuk dalam pencapaian 'tepat jumlah', 'tepat jenis' dan 'tepat tempat'.

\section{a) Tepat jumlah}

Ketepatan jumlah pupuk subsidi mengacu pada pemenuhan alokasi pupuk oleh PT. Pupuk Indonesia sesuai ketetapan dalam Peraturan Menteri Pertanian. Perbandingan dilakukan antara realisasi jumlah per jenis pupuk subsidi yang terjual dari PT. Pupuk Indonesia dengan jumlah per jenis pupuk sesuai dengan perjanjian yang dituangkan dalam Public Service Obligation (PSO).

Tabel 2 menjelaskan bahwa pada kurun waktu 20112015, kinerja seluruh jenis pupuk rata-rata 91,61\% Berdasarkan standar skala efektivitas acuan Champion DJ dalam Basic Statistic for Statistical Research (1981) bisa disebut bahwa subsidi pupuk sangat efektif karena mencapai 'tepat jumlah'. Namun demikian, yang lebih penting untuk dijadikan acuan adalah target yang ditetapkan pemberi program. Jika target yang ditetapkan adalah 100\% maka subsidi pupuk dianggap belum efektif mencapai tepat jumlah. Tabel 2 mendeskripsikan pencapaian 'tepat jumlah' pada 20112015.

Dari sisi perusahaan, ketidaktepatan antara jumlah PSO dengan realisasi pupuk yang terjual sebenarnya merupakan wujud ketidakcermatan perencanaan. Namun, BUMN produsen pupuk juga harus memahami bahwa pupuk bersubsidi merupakan produk yang harus dijamin ketersediaannya oleh pemerintah pada saat petani membutuhkan, sehingga mereka harus selalu memiliki stok yang cukup. Kelangkaan pupuk bukan saja akan merugikan petani, namun bisa berimbas luas. Olehkarenanya Pemerintah selalu menjaga angka PSO di atas kebutuhan riil petani. Namun, pembayaran subsidi tetap mengacu pada realisasi penjualan pupuk bersubsidi berdasarkan hasil audit BPK. Kelebihan
PSO yang tidak terserap biasanya akan dijual produsen sebagai pupuk non subsidi.

Ketidaksesuaian antara PSO dengan realisasi jumlah pupuk yang terjual bisa juga menunjukkan terjadinya ketidaktepatan dosis penggunaan pupuk subsidi di tingkat petani. Hasil penelitian Vidyanita et al. (2013) di salah satu kecamatan di Kabupaten Jombang Jawa Timur menyebutkan bahwa $85 \%$ petani tidak memenuhi kaidah 'tepat jumlah' dalam pemupukan. Sebagian besar dari mereka (86\%) menggunakan pupuk dengan dosis di atas anjuran.

b) Tepat jenis

Kinerja tepat jenis pupuk bersubsidi diukur dengan membandingkan realisasi penjualan pupuk bersubsidi berdasar jenis (urea, ZA, SP36, NPK, Organik) produsen dengan penugasan/target (PSO) pemerintah kepada produsen.

Berdasarkan standar skala efektivitas acuan, bisa disebut terlihat bahwa subsidi pupuk sangat efektif dalam mencapai 'tepat jenis' karena seluruh jenis pupuk bersubsidi nilai efektivitasnya di atas $75 \%$.

Tabel 3 menjelaskan, pada periode 2011-2015, seluruh jenis pupuk anorganik, yaitu urea, SP36, ZA dan NPK nilai ketepatannya di atas $90 \%$, sementara pupuk organik walaupun nilai ketepatannya $80,21 \%$. Namun, nilainya jauh lebih rendah dibanding pupuk anorganik. Ketepatan pupuk organik yang rendah dikarenakan masih terbatasnya pemakaian pupuk organik oleh petani sebagai akibat sulitnya mengubah preferensi petani dari penggunaan pupuk kimia ke pupuk organik. Kondisi ini tentunya akan menghambat program pemerintah terkait pupuk bersubsidi yang akan meningkatkan penyerapan pupuk organik dan pupuk majemuk disertai dengan pengurangan produksi dan distribusi pupuk tunggal.

Tabel 2. Kinerja subsidi pupuk kategori tepat jumlah

\begin{tabular}{|c|c|c|c|}
\hline Tahun & Realisasi Penjualan (Ton) & Jumlah PSO (Ton) & Efektivitas (Persen) \\
\hline 2011 & 8.386 .113 & 9.733 .224 & 86,16 \\
\hline 2012 & 8.953 .316 & 10.528 .920 & 85,04 \\
\hline 2013 & 8.831 .810 & 8.611 .050 & 102,56 \\
\hline 2014 & 8.897 .648 & 9.550 .000 & 93,17 \\
\hline 2015 & 8.881 .084 & 9.550 .000 & 93,00 \\
\hline $2011-2015$ & 43.949 .971 & 47.973 .194 & 91,61 \\
\hline
\end{tabular}


Tabel 3. Kinerja subsidi pupuk kategori tepat jenis

\begin{tabular}{lc}
\hline Jenis Pupuk & Efektivitas 2011-2015 (\%) \\
\hline Urea & 92,38 \\
SP36 & 94,51 \\
ZA & 96,95 \\
NPK & 90,96 \\
Organik & 80,21 \\
Seluruh jenis pupuk & 91,61 \\
\hline
\end{tabular}

Produksi dan distribusi setiap jenis pupuk bersubsidi dilakukan oleh PT. Pupuk Indonesia melalui lima anak perusahaan pupuk. Seluruh produsen bertugas memproduksi dan memasarkan pupuk bersubsidi jenis urea tetapi dengan volume (tonase) yang berbeda-beda. PT. Pupuk Kalimantan Timur yang memiliki kapasitas produksi dan jaringan pemasaran paling besar mendapat beban paling tinggi. Wilayah kerjanya pupuk urea bersubsidi meliputi kawasan timur Indonesia, termasuk sebagian Jawa dan Kalimantan. Empat Produsen lain juga mendapatkan penugasan memproduksi dan mendistribusikan pupuk urea, tetapi dengan volume yang lebih kecil dan kawasan pemasaran hanya di sekitar produsen berproduksi. Seluruh produsen juga mendapatkan penugasan memproduksi/kerjasama produksi pupuk organik bersubsidi dan memasarkannya di wilayah sesuai dengan penugasan yang diberikan. Khusus untuk pupuk ZA, SP36 dan NPK dominan penugasannya diberikan kepada PT. Pupuk Petrokimia Gresik berikut pemasarannya ke seluruh wilayah Indonesia. Dua produsen lain yaitu PT. Pupuk Kujang Cikampek dan PT. Pupuk Kalimantan Timur juga mendapatkan tambahan penugasan produksi dan pemasaran pupuk NPK dengan wilayah distribusi terbatas.

\section{c) Tepat tempat}

Dalam penyaluran pupuk subsidi, ketepatan tempat menunjukkan bagaimana produsen bisa mendistribusikan produksinya ke wilayah yang ditetapkan dalam PSO. Dalam penelitian ini, wilayah yang dimaksud adalah provinsi yang menjadi lokasi distribusi pupuk bersubsidi.

Tabel 4 mendeskripsikan efektivitas subsidi pupuk dalam kategori "tepat tempat" representasi provinsi. Dari 32 provinsi, hasilnya menunjukkan bahwa efektivitas bernilai tinggi dalam 'ketepatan tempat' paling ideal terjadi di Jawa Timur. Data menunjukkan bahwa pada seluruh jenis pupuk, realisasi jumlah distribusi mendekati jumlah yang ditetapkan dalam PSO. Keberhasilan Jawa Timur disebabkan dalam hal initerkait dengan tingginya keterlibatan pemerintah daerah dan pemangku kepentingan tingkat pelaksana (kelompok tani, kios, distributor) dalam proses perencanaan maupun pelaksanaan pupuk bersubsidi. Selain Jawa Timur, Beberapa provinsi lain yang nilai "efektivitas tempatnya" tinggi yaitu Nusa Tenggara Timur, Kalimantan Barat, Kalimantan Tengah dan Gorontalo masih memiliki catatan dikarenakan beberapa jenis pupuk terutama NPK dan ZA realisasinya melebihi yang ditetapkan dalam PSO (perencanaan yang tidak cermat).

Kepulauan Riau merupakan salah satu provinsi dengan nilai efektivitas tepat tempat yang paling rendah. Menurut standar skala efektivitas acuan, nilai efektivitas 30,22 menunjukkan bahwa program pupuk bersubsidi di Kepulauan Riau hanya sedikit efektif. Hal tersebut disebabkan karena wilayahnya yang sebagian besar kepulauan menyulitkan distribusi pupuk bersubsidi di Kepulauan Riau.

Apabila dibandingkan antar provinsi, terlihat bahwa provinsi yang kinerja 'tepat tempat' nya rendah umumnya adalah provinsi yang berada di Wilayah Timur Indonesia (WTI), yaitu Maluku, Maluku Utara, Papua Barat dan Papua. Hal tersebut disebabkan karena jarak provinsi yang jauh dari produsen sehingga mendapatkan respon yang lebih lambat dibanding daerah-daerah yang lokasinya lebih dekat. Distribusi pupuk bersubsidi di wilayah yang jauh dari produsen juga membutuhkan waktu yang lebih lama dan biaya yang bisa menjadi alasan mengapa ketepatan tempat di wilayah timur Indonesia lebih rendah dibanding wilayah lain. Prakiraan kebutuhan pupuk yang dibuat secara agregat dengan hanya mempertimbangkan luas tanam dan takaran pupuk secara umum mengakibatkan kebutuhan riil dengan ketersediaan pupuk sering berbeda nyata sehingga ada daerah yang kelebihan dan banyak daerah juga yang kekurangan (PSE-KP, 2006).

Hasil penilaian kinerja 'tepat tempat' juga memberikan hasil menarik, karena beberapa provinsi di mana produsen pupuk yang kontrak PSO berdomisili, nilai efektivitasnya lebih rendah dibanding provinsi lain, yaitu Sumatera Selatan (dengan produsen PT. Pupuk Sriwidjaya Palembang), Jawa Barat (dengan produsen PT. Pupuk Kujang) dan Kalimantan Timur (dengan produsen PT. Pupuk Kaltim). Ketiga produsen tersebut 
berdasarkan PSO berkewajiban memproduksi pupuk urea bersubsidi. Namun, nilai efektivitas tepat tempat untuk urea di ketiga provinsi tersebut kurang dari $90 \%$.

Dalam rangka meningkatkan ketepatan penyaluran pupuk bersubsidi, perlu peningkatan peran aktif pemerintah daerah (provinsi/kabupaten/kota) dalam pemantauan penyediaan dan penyaluran pupuk bersubsidi di wilayahnya. Rachman (2012) mengusulkan untuk menjamin bahwa pupuk bersubsidi yang didistribusikan di wilayahnya sampai ke petani dan/atau kelompok tani sebagai konsumen akhir, pemerintah daerah perlu mempersiapkan kelembagaan dan infrastruktur distribusi pupuk bersubsidi melalui pemberdayaan BUMD. Penelitian Yuliani (2015) menjelaskan bahwa untuk kasus di kabupaten Rokan Hilir, peningkatan ketepatan penyaluran pupuk bersubsidi akan dapat dicapai jika pemerintah daerah berperan aktif dalam pemantauan penyediaan dan penyaluran pupuk bersubsidi di wilayahnya.

Tabel 4. Efektivitas subsidi pupuk kategori tepat tempat

\begin{tabular}{|c|c|c|c|c|c|c|}
\hline \multirow{2}{*}{ Provinsi } & \multicolumn{6}{|c|}{ Tepat tempat } \\
\hline & Total & Urea & SP36 & $\mathrm{ZA}$ & NPK & Organik \\
\hline Nangroe Aceh Darussalam & 91,12 & 93,60 & 97,80 & 100,09 & 91,66 & 64,94 \\
\hline Sumatera Utara & 89,12 & 90,47 & 97,82 & 95,35 & 87,85 & 66,90 \\
\hline Sumatera Barat & 91,37 & 90,77 & 96,41 & 88,42 & 94,68 & 77,98 \\
\hline Riau & 91,91 & 89,63 & 92,94 & 95,44 & 95,24 & 78,00 \\
\hline Jambi & 92,09 & 90,12 & 92,54 & 100,49 & 95,27 & 72,05 \\
\hline Sumatera Selatan & 85,41 & 88,78 & 93,01 & 74,96 & 81,08 & 66,36 \\
\hline Bengkulu & 88,87 & 88,89 & 93,15 & 90,87 & 90,25 & 73,16 \\
\hline Lampung & 90,00 & 90,45 & 87,83 & 88,41 & 92,30 & 78,25 \\
\hline Kepulauan Bangka Belitung & 89,56 & 92,03 & 88,81 & 88,63 & 91,08 & 75,15 \\
\hline Kepulauan Riau & 30,22 & 26,28 & 16,19 & 31,27 & 38,54 & 16,22 \\
\hline Jawa Barat & 88,59 & 88,02 & 97,30 & 93,73 & 89,14 & 63,81 \\
\hline Jawa Tengah & 92,58 & 94,16 & 95,85 & 95,27 & 92,22 & 81,99 \\
\hline DI Yogyakarta & 82,48 & 81,33 & 79,54 & 92,26 & 85,53 & 74,27 \\
\hline Jawa Timur & 95,82 & 95,08 & 95,52 & 99,98 & 96,00 & 91,81 \\
\hline Banten & 84,24 & 87,04 & 95,47 & 79,68 & 72,68 & 79,35 \\
\hline Bali & 79,30 & 85,46 & 67,01 & 79,22 & 71,26 & 77,95 \\
\hline Nusa Tenggara Barat & 94,03 & 96,71 & 94,16 & 89,96 & 87,94 & 90,27 \\
\hline Nusa Tenggara Timur & 96,12 & 94,87 & 87,57 & 79,50 & 106,72 & 96,71 \\
\hline Kalimatan Barat & 96,51 & 92,25 & 90,50 & 86,24 & 105,41 & 79,40 \\
\hline Kalimantan Tengah & 96,86 & 90,79 & 89,89 & 80,40 & 104,77 & 81,36 \\
\hline Kalimantan Selatan & 89,23 & 84,98 & 92,85 & 68,49 & 99,04 & 68,38 \\
\hline Kalimantan Timur & 86,97 & 85,34 & 86,44 & 80,19 & 91,76 & 55,13 \\
\hline Sulawesi Utara & 81,65 & 82,22 & 82,97 & 74,90 & 84,09 & 60,71 \\
\hline Sulawesi Tengah & 87,33 & 88,44 & 70,95 & 83,31 & 93,56 & 68,41 \\
\hline Sulawesi Selatan & 94,93 & 94,74 & 98,82 & 100,59 & 90,36 & 75,64 \\
\hline Sulawesi Tenggara & 86,66 & 81,72 & 96,60 & 88,50 & 95,12 & 73,24 \\
\hline Gorontalo & 96,79 & 104,84 & 79,90 & 68,62 & 93,31 & 57,65 \\
\hline Sulawesi Barat & 92,05 & 92,95 & 83,83 & 95,99 & 97,52 & 40,82 \\
\hline Maluku & 76,40 & 79,78 & 52,45 & 42,42 & 86,87 & 53,98 \\
\hline Maluku Utara & 69,33 & 59,01 & 39,87 & 60,63 & 89,31 & 55,75 \\
\hline Papua Barat & 81,76 & 86,38 & 87,83 & 54,31 & 84,97 & 50,64 \\
\hline Papua & 85,83 & 87,93 & 83,92 & 80,26 & 90,18 & 69,38 \\
\hline
\end{tabular}


Ketepatan Penyaluran Pupuk Bersubsidi sebagaimana dicantumkan dalam Permendag No. 21/MDAG/ PER/6/2008, penyaluran adalah proses pendistribusian pupuk bersubsidi dari produsen sampai petani dan/ atau kelompok tani sebagai konsumen akhir. Sebagai konsekuensinya, pemerintah daerah mulai dari tingkat provinsi, kabuputen/kota sampai kecamatan dan desa/ kelompok tani perlu mempersiapkan kelembagaan dan infrastruktur distribusi pupuk bersubsidi melalui pemberdayaan Badan Usaha Milik Daerah (BUMD) yang mampu melaksanakan penyaluran pupuk bersubsidi secara langsung kepada kelompok tani/ gabungan kelompok tani. Untuk meningkatkan efektivitas dan ketepatan penyaluran pupuk bersubsidi, perlu peningkatan peran aktif pemerintah daerah (provinsi/kabupaten/kota) melalui Dinas Pertanian dalam pemantauan penyediaan dan penyaluran pupuk bersubsidi di wilayahnya.

Hasil penting lainnya adalah data yang menunjukkan rata-rata kinerja 'tepat tempat' yang rendah pada jenis pupuk organik. Rendahnya kinerja 'tepat tempat' untuk pupuk organik salah satunya disebabkan tidak seluruh pupuk organik diproduksi oleh produsen, tetapi oleh mitra produsen. Kinerja 'tepat tempat' untuk pupuk organik yang rendah menunjukkan bahwa mitra produsen dan atau produsen belum optimal dalam memproduksi dan mendistribusikan pupuk organik. Hasil penelitian Arisandi et al. (2016) bahwa ketidakefektifan subsidipupuk organik ditunjukkan oleh ketidaksesuaian RDKK yang diterima produsen pupuk dengan kebutuhan riil responden Subak Sungsang.

\section{Implikasi Manajerial}

Pemerintah harus menerapkan strategi yang tepat dalam subsidi pupuk di Indonesia mengingat anggaran yang dibutuhkan sangat besar dan stakeholders yang terlibat juga cukup heterogen. Kebijakan subsidi pupuk juga terkait erat dengan keberpihakan pemerintah kepada petani dan ketersediaan pangan nasional.

Tanggungan hutang subsidi pupuk yang harus dibayar pemerintah kepada produsen signifikan memengaruhi keputusan besaran anggaran yang secara riil digunakan untuk mensubsidi pupuk pada tahun-tahun berikutnya. Oleh karena itu, Kementerian Keuangan harus mengelola pembayaran hutang subsidi ini dengan cara: 1) menjadwalkan pembayaran hutang subsidi dan bunganya setiap tahun berikut besaran hutang dan bunga yang harus dibayar; 2) menetapkan jangka waktu pelunasan pembayaran hutang berikut bunganya; 3) memisahkan pos anggaran pembayaran hutang subsidi dengan anggaran subsidi riil. Dengan menerapkan ketiga hal tersebut, maka jatah riil anggaran subsidi pupuk diharapkan tidak terganggu.

Hasil penelitian disebutkan bahwa RDKK tidak berpengaruh terhadap keputusan pemerintah dalam menetapkan anggaran pupuk, padahal penyusunan RDKK bukan tanpa biaya dan tenaga. Oleh karena itu Kementerian Pertanian harus mengevaluasi kembali kinerja RDKK jika akan digunakan sebagai dasar pengajuan subsidi pupuk.

Data penyerapan pupuk tahun sebelumnya signifikan berpengaruh terhadap kinerja subsidi pupuk di Indonesia, sehingga Kementerian Pertanian bisa mengoptimalkan peran produsen (PT Pupuk Indonesia) untuk melakukan pengumpulan data penyerapan per jenis pupuk subsidi, wilayah dan jenis tanaman/ perikanan per tahunnya dan menjamin keakuratan datanya.

Pupuk organik merupakan jenis pupuk yang ketepatan jenis dan tempat nya paling rendah dibanding pupuk anorganik. Kementerian Pertanian harus mempromosikan produksi, distribusi maupun penggunaan pupuk organik melalui sosialisasi masif pentingnya pupuk organik kepada stakeholders terkait.

Enam tepat merupakan syarat yang ditetapkan pemerintah kepada produsen dalam produksi dan distribusi pupuk bersubsidi. Namun demikian, sampai saat ini tidak ada mekanisme untuk memastikan enam tepat tersebut dapat dicapai atau tidak. Oleh karena itu, pemerintah sebaiknya menetapkan pencapaian enam tepat sebagai bagian dari evaluasi keberhasilan penugasan subsidi pupuk kepada PT Pupuk Indonesia. Kegiatan bisa dilakukan oleh pihak independen (lembaga penelitian) atau self asessment oleh PT Pupuk Indonesia. Rumusan enam tepat bisa mengacu rumusan yang dihasilkan dari penelitian ini dengan perluasan sesuai kebutuhan, misalnya analisis per pabrik pupuk, per jenis pupuk, per provinsi, dan seterusnya. 


\section{KESIMPULAN DAN SARAN}

\section{Kesimpulan}

Faktor-faktor yang berpengaruh signifikan menaikkan anggaran subsidi pupuk adalah peningkatan penyerapan pupuk tahun sebelumnya, peningkatan dana perbantuan pemerintah pusat kepada pemerintah provinsi serta peningkatan PDRB provinsi. Peningkatan hutang subsidi pemerintah kepada produsen akan menurunkan anggaran subsidi. Usulan kebutuhan pupuk yang disampaikan oleh kelompok tani melalui RDKK tidak dijadikan dasar oleh pemerintah dan DPR dalam menetapkan anggaran subsidi pupuk. Tingkat efektivitas pupuk organik lebih rendah dibanding pupuk anorganik, ditunjukkan oleh nilai tepat jenis yang hanya $80 \%$ dan tepat tempat di bawah $75 \%$.

\section{Saran}

Hasil yang diperoleh tersebut disarankan untuk melakukan penelitian empiris dengan menggunakan data primer terkait faktor-faktor yang memengaruhi kinerja subsidi pupuk untuk lebih memperkaya hasil penelitian ini. Penelitian empiris lain terkait 'tepat waktu', 'tepat mutu' dan 'tepat harga' disarankan juga dilakukan untuk melengkapi hasil penelitian sekunder ini yang baru mengukur 'tepat jenis', 'tepat jumlah' dan 'tepat tempat'.

\section{DAFTAR PUSTAKA}

Alimoeso S. 2010. Ketersediaan pupuk 2010-2014. Jurnal Pangan 19 (1): 40-50.

Arisandi NW, Sudarma IM, Rantau K. 2016. Efektivitas distribusi subsidi pupuk organik dan dampaknya terhadap pendapatan usahatani padi sawah di Subak Sungsang, Desa Tibubiu, Kabupaten Tabanan. Jurnal Agribisnis dan Agrowisata 5(1): $1-10$.

Armas EB, Osorio CG, Dodson BM, Abriningrum DE. 2010. Agriculture public spending and growth: the example of Indonesia. Economic Premise Journal of the World Bank 9(1):1-33.

Champion DJ. 1981. Basic Statistics for Social Research/Edition 2. New York: Mac Milan Publishing Company.

Darwis V, Supriyati. 2013. Subsidi pupuk: kebijakan, pelaksanaan dan optimalisasi pemanfaatannya. Analisis Kebijakan Pertanian 11(1): 45-60. https://doi.org/10.21082/akp.v11n1.2013.45-60.

Hendrawan DS, Daryanto A, Sanim B, Siregar H. 2011. Analisis kebijakan subsidi pupuk: penentuan pola subsidi dan sistem distribusi pupuk di Indonesia. Jurnal Manajemen dan Agribisnis 8(2): 85-96.

Hutagaol MP, Asmara A. 2008. Analisis efektivitas kebijakan publik memihak masyarakat miskin: studi kasus pelaksanaan program raskin di Provinsi Jawa Barat pada Tahun 2007. Jurnal Agro Ekonomi 25(2):145-165. https://doi. org/10.21082/jae.v26n2.2008.145-165.

Ilham N, Siregar H, Priyarsono DS. 2006. Efektivitas kebijakan harga pangan terhadap ketahanan pangan. Jurnal Agro Ekonomi 24(2): 157-177. https://doi.org/10.21082/jae.v24n2.2006.157177.

[KPPN/BAPPENAS] Kementerian Perencanaan Pembangunan Nasional/Badan Perencanaan Pembangunan Nasional. 2011. Kajian Strategis Kebijakan Subsidi Pertanian yang Efektif, Efisien dan Berkeadilan. Jakarta:KPPN/BAPPENAS.

[PSE-KP] Pusat Analisis Sosial Ekonomi dan Kebijakan Pertanian. 2006. Konstruksi Kebijakan Pupuk 2006. Bogor: PSE-KP.

Rachman B. 2009. Kebijakan subsidi pupuk: tinjauan terhadap aspek teknis, manajemen dan regulasi. Analisis Kebijakan Pertanian 7(2):131-148.

Rachman B. 2012. Tinjauan kritis dan perspektif sistem subsidi pupuk. Jurnal Litbang Pertanian 31(3): 119-127.

Rachman B, Sudaryanto T. 2010. Impacts and future perspectives of fertilizer policy in Indonesia. Analisis Kebijakan Pertanian 8(3):193-205. https://doi.org/10.21082/akp.v8n3.2010.193205.

Safitri A, Supriyono B, Ribawanto H. 2013. Distribusi pupuksubsidikepadapetani tebu dalam perspektif manajemen publik (Studi pada koperasi unit desa di Sumberpucung Kabupaten Malang). Jurnal Administrasi Publik 1(1): 102-109.

Suryana A, Agustian A, Yofa RD. 2016. Alternatif kebijakan penyaluran subsidi pupuk bagi petani pangan. Analisis Kebijakan Pertanian 14(1): 3554.https://doi.org/10.21082/akp.v14n1.2016.3554.

Susila W. 2010. Kebijakan subsidi pupuk: ditinjau kembali. Jurnal Litbang Pertanian 29(2): 4349.

Syafaat N, Purwoto A, Muslim C. 2006. Analisis Besaran Subsidi Pupukdan PolaDistribusiannya. Bogor: Pusat Analisis Sosial Ekonomi dan 
Kebijakan Pertanian.

Trisnanto A, Daryanto A, Hendriadi A. 2015. Pengaruh belanja pemerintah pusat terhadap peningkatan produksi padi di Provinsi Jawa Barat. Jurnal Agro Ekonomi 33(1): 1-15. https://doi.org/10.21082/ jae.v33n1.2015.1-15.
Vidyanita V, Wijaya AF, Rochmah S. 2016. Kinerja birokrasi dalam penyaluran pupuk bersubsidi di Kecamatan Jombang. Jurnal Ilmu Sosial dan Ilmu Politik 5(1): 74-85.

Yuliani F. 2015. Efektivitas implementasi kebijakan pupuk subsidi pada tanaman pangan di Kabupaten Rokan Hilir. Spirit Publik 10(1): 133-162. 